\title{
ANALISIS IMPLEMENTASI KEBIJAKAN BANTUAN OPERASIONAL SEKOLAH BUKU UNTUK SEKOLAH DASAR
}

\author{
Bambang Wasito Adi, Misbah Fikrianto, Suratni \\ Program Studi Penerbitan, Politeknik Negeri Media Kreatif
}

\begin{abstract}
Abstrak
Tujuan penelitian ini adalah (1) untuk melihat sejauh mana implementasi kebijakan BOS Buku ditinjau dari sumber anggaran untuk penyediaan buku; (2) untuk menganalisis hambatan/masalah yang ada dari implementasi kebijakan BOS buku; dan (3) untuk mencari dan memberikan solusi terhadap hambatan-hambatan tersebut. Penelitian dilaksanakan secara terbatas pada 15 sekolah dasar pada empat kecamatan di kota Depok. Metode yang digunakan adalah kuantitatif dan kualitatif (mixed method) dengan cara pengambilan data melalui survei dan kuesioner deskriptif. Analisis yang telah digunakan adalah dengan persentase dan deskriptif kualitatif. Variabel dalam penelitian ini adalah variabel tunggal yaitu implementasi kebijakan pemerintah mengenai BOS Buku. Hasil Penelitian mencakup tiga hal utama. Pertama, bahwa sumber anggaran untuk penyediaan buku di sekolah berasal dari BOS Reguler, APBD, orangtua siswa, dan sponsor untuk sekolah swasta. Dalam implementasinya, sebanyak 8 sekolah (53\%) menyatakan anggaran tersebut cukup dan 7 sekolah $(46,6 \%)$ menyatakan sebaliknya. Kedua, masalah yang ada dalam implementasi kebijakan BOS Buku adalah ketersediaan buku yang tidak mencukupi dengan rasio 1 buku : 1 siswa, proses pelaporan administrasi BOS yang rumit, dan dana BOS pada implementasinya mengalami keterlambatan. Terakhir, peneliti memberikan solusi terhadap masalah-masalah yang ada kepada berbagai pihak terkait, pemerintah pusat, pemerintah daerah, sekolah, orang tua siswa, dan penerbit/agen buku.
\end{abstract}

Kata kunci: implementasi BOS Buku, sekolah dasar, kota Depok 


\section{PENDAHULUAN}

Meningkatnya
kebutuhan
pemerintah Indonesia menyalurkan
berbagai bantuan demi kelangsungan
pendidikan di Indonesia, salah
satunya adalah dana Bantuan

Operasional Sekolah (BOS). Dana BOS diperuntukkan untuk tingkat pendidikan dasar di Indonesia dengan tujuan mengurangi beban biaya pendidikan demi tuntasnya wajib belajar sembilan tahun yang bermutu.Secara khusus seluruh siswa di tingkat pendidikan dasar negeri maupun swasta bebas dari beban biaya operasional sekolah. Seluruh siswa Sekolah Dasar (SD) dan Sekolah Menengah Pertama (SMP) negeri bebas dari biaya operasional sekolah, kecuali Rintisan Sekolah Bertaraf Internasional (RSBI) dan Sekolah Bertaraf Internasional (SBI). Namun masih kita temukan berbagai kendala dalam penyaluran dan realisasi dana Bantuan Operasional Sekolah (BOS).

Salah satu kegunaan dana BOS adalah untuk pembelian buku teks pelajaran, atau lebih dikenal dengan nama BOS Buku. Dalam penelitian ini, para peneliti berusaha mempelajari tentang dana BOS Buku, mencari setiap kendala dan kasus, hingga berusaha mencari solusi dari setiap kendala yang ada. BOS merupakan dana yang digunakan oleh sekolah sesuai dengan panduan yang telah ada. Oleh karena itu, sekolah harus melaksanakannya sesuai dengan pos dana yang ada. Pada tahun 2007 sampai dengan 2008, pemerintah pusat memberikan dana BOS dengan dua scheme, yaitu BOS Reguler dan BOS Buku.

Dana tersebut diberikan secara terpisah dan langsung ke sekolah. Pada tahun 2009 sampai dengan 2010, dana BOS Buku sudah tidak ada lagi, dan pembiayaan untuk buku teks include ke dalam anggaran BOS Reguler. Proses pencairan dana tersebut melalui pemerintah propinsi dan langsung ke rekening sekolah. Pada tahun 2011, dana BOS Reguler akan dimasukkan ke dalam anggaran APBD Tingkat II. Oleh karena itu, sekolah harus menyesuaikan dan berkoordinasi dengan pemerintah daerah tingkat II mengenai implementasi dana BOS.

Kegiatan penelitian ini memiliki tujuan, yaitu: 
1. untuk melihat sejauh mana implementasi kebijakan BOS Buku ditinjau dari sumber anggaran untuk penyediaan buku;

2. untuk menganalisis hambatan/masalah yang ada dari implementasi kebijakan BOS buku;

3. untuk mencari dan memberikan solusi terhadap hambatanhambatan tersebut.

\section{METODE PENELITIAN}

Metode yang digunakan adalah gabungan metode kuantitatif dan metode kualitatif (Mixed Method) dengan cara pengambilan data melalui survei ke sekolah dasar di wilayah kota Depok dan kuesioner deskriptif. Penggunaan instrumen penelitian terbuka, maka metode analisis data ini lebih banyak menggunakan analisis data kualitatif. Analisis data kualitatif dari data empiris penelitian pada akhirnya menjadi sebuah kesimpulan penelitian. Analisis yang digunakan adalah dengan persentase dan deskriptif kualitatif.

\section{HASIL DAN PEMBAHASAN}

Bagian ini menjelaskan analisis hasil penelitian mengenai "Analisis Implementasi Kebijakan Bantuan Operasional Sekolah Buku untuk Sekolah Dasar" Pembahasan analisis hasil penelitian ini dimulai dari analisis kualitatif yang meliputi profil responden, analisis deskripsi variabel penelitian, dan penjelasan pada komponen sumber anggaran penyediaan buku, buku teks pelajaran, buku panduan pendidik (pegangan guru), buku pengayaan, serta buku latihan kerja siswa. Pengumpulan data penelitian dilakukan dengan cara memberikan kuesioner dan wawancara kepada responden penelitian yaitu pada 15 sekolah dasar, yaitu SDN Pondok Cina 02, SDN Pondok Cina 05, SDN Beji Timur 01, SDN Beji Timur 02, SDN Sawangan 01, SDN Sawangan 02, SDN Pengasinan 01, SDN Pengasinan 02, SDN Duren Seribu 01, SDN Duren Seribu 02, SDS Perjuangan Terpadu, SDN Kukusan 01, SDN Pondok Cina 01, SDN Pondok Cina 04, dan SDS Al Hikmah yang diambil dengan menggunakan metode purposive sampling. 
Dalam penelitian ini disebarkan 15 kuesioner pada 15 responden. Kuesioner yang terjawab lengkap dengan baik dan layak dianalisis dalam penelitian ini sebanyak 15 kuesioner $(100 \%)$. Rincian perolehan kuesioner dalam penelitian ini dapat dilihat pada lampiran rekapitulasi data. Setelah data terkumpul, kemudian data diedit (editing), diberi kode (coding), dan ditabulasikan (tabulating).

\section{Profil Responden}

Berdasarkan hasil penelitian yang telah dilakukan terhadap 15 reponden, maka dapat diidentifikasikan mengenai karakteristik responden sebagai berikut.

Gender; berdasarkan gender, maka responden dalam penelitian ini diklasifikasikan sebagai berikut.

Tabel 1 Klasifikasi Responden Berdasarkan Gender

\begin{tabular}{|c|c|c|c|}
\hline No & Gender & Jumlah & $\%$ \\
\hline 1 & Laki-laki & 12 & 80 \\
\hline 2 & Perempuan & 3 & 20 \\
\hline \multicolumn{2}{|l|}{ Total } & 15 & 100 \\
\hline
\end{tabular}

Sumber : Data Primer Diolah, 2011
Berdasarkan Tabel 1, responden dalam penelitian ini sebagian besar adalah laki-laki, yaitu sebanyak 12 responden (80\%) dan perempuan sebanyak 3 responden (20\%).

Jabatan, berdasarkan penghasilan maka responden dalam penelitian ini diklasifikasikan sebagai berikut.

Tabel 2 Klasifikasi Responden Berdasarkan Jabatan

\begin{tabular}{|c|l|c|c|}
\hline No & \multicolumn{1}{|c|}{ Jabatan } & Jumlah & $\%$ \\
\hline 1 & Kepala Sekolah & 9 & 60 \\
\hline 2 & Guru & 6 & 40 \\
\hline \multicolumn{2}{|c|}{ Total } & 15 & 100 \\
\hline
\end{tabular}

Sumber : Data Primer Diolah, 2011

Berdasarkan Tabel 2 bahwa responden dalam penelitian ini adalah sebagian besar berkedudukan sebagai kepala sekolah, yaitu sebanyak 9 responden (60\%) dan sebagian kecil adalah guru kelas, sebanyak 6 responden $(40 \%)$.

\section{Deskripsi tentang Responden dan}

Objek yang Digunakan untuk

\section{Penelitian}

Seperti tersebut pada sebelumnya bahwa ada 15 responden yang digunakan dalam penelitian ini. Sedangkan variabel yang 
dikemukakan adalah "Implementasi

Bantuan Operasional Sekolah Buku untuk Sekolah Dasar".

Berdasar hal tersebut maka uraian tentang hasil dari penelitian lapangan dilaporkan sebagai berikut.

a. penelitian dilakukan di 4 (empat)

Kecamatan, yaitu Kecamatan

Beji, Kecamatan Sawangan,

Kecamatan Bojong Sari, dan

Pancoran Mas dengan jumlah

responden sebanyak 15. Sampel

yang diambil terdapat 2 sekolah

dasar swasta, yaitu SDS

Perjuangan dan SDS Al Hikmah;

b. penelitian dilakukan secara langsung dengan datang ke sekolah dan melakukan wawancara langsung;

c. penelitian juga melihat kelayakan (sampel) buku-buku yang digunakan oleh sekolah maupun buku-buku yang dijual umum di pasaran;

d. mekanisme penelitian, Tim membagi beberapa sekolah untuk didatangi secara bergantian dan satu sekolah didatangi secara bersama-sama;

e. setelah itu, Tim Penelitian melakukan pengolahan data dan pembuatan pelaporan penelitian.

\section{Implementasi Kebijakan BOS}

Buku Ditinjau dari Sumber

Anggaran untuk Penyediaan Buku

\section{Sekolah}

Dilihat dari Implementasi BOS Buku ditinjau dari aspek Sumber Anggaran untuk Penyediaan Buku Sekolah maka dapat dijelaskan sebanyak $100 \%$ dari sampel menyatakan bahwa sumber anggaran berasal dari: BOS regular, APBD, Siswa, dan terdapat 2 sekolah (13\%) yang mendapatkan anggaran tambahan dari sumber-sumber lain.

Sumber-sumber lain tersebut berasal dari bantuan donator dan kerjasama dengan pihak-pihak lain. Melihat kondisi data tersebut maka dapat disimpulkan bahwa sumber anggaran secara umum sama.

Jumlah anggaran untuk pembelian buku relatif sama, yaitu Rp 10.000 untuk satu bukunya. Pada tahun 2010, sekolah mengadakan 2 buku teks, yaitu agama dan seni budaya. Pada tahun 2011, sekolah akan mengadakan buku Pendidikan jasmani olahraga kesehatan. Sebanyak 8 sekolah $\quad(53 \%)$ menyatakan anggaran tersebut cukup, dan 7 sekolah $(46,6 \%)$ 
menyatakan anggaran tersebut tidak cukup.

\section{Lembar Kerja Siswa}

Buku LKS sebanyak 13 sekolah $(86,6 \%)$ tidak mendapatkan daftar dari dinas pendidikan kota Depok. Dana BOS untuk membelikan LKS hanya satu sekolah yang menggunakannya, yaitu SDN Pengasinan 01, yang lainnya tidak menggunakan dana BOS tetapi menggunakan dana dari siswa (orang tua). Sekolah tidak mennyediakan anggaran khusus, kecuali SDN Pengasinan 01 sebanyak Rp 7.200.000. Kebutuhan ideal dana untuk pembelian LKS berkisar antara Rp 7000 s.d 8000 per LKS per mata pelajaran, jadi jumlahnya hampir sama dan yang berbeda hanya jumlah siswanya.

Hambatan dalam pengadaan buku LKS, yaitu dukungan orangtua yang kurang, hal ini akan menjadikan tidak semua peserta didik memiliki buku lks. Hal ini akan membuat proses pembelajaran yang kurang optimal. LKS merupakan bahan praktik siswa terhadap materi yang diberikan pada buku teks, jadi fungsi lks sangat penting.

\section{Masalah-masalah yang Ada pada Implementasi Kebijakan BOS Buku}

Implementasi BOS Reguler secara umum baik dilihat dari pembelian buku, sejak tahun 2009 sudah tidak ada lagi dana BOS buku yang turun ke sekolah, sekolah hanya menerima dana BOS Reguler. Oleh karena itu, anggaran untuk penyediaan buku di sekolah include di dalam anggaran tersebut. Sekolah hanya membeli buku yang disyaratkan dalam petunjuk pelaksanaan dana BOS. Oleh karena itu terdapat beberapa masalah, diantaranya sebagai berikut.

1. ketersediaan buku yang tidak mencukupi dengan rasio 1 buku: 1 siswa, karena terkadang sekolah mengalami kendala teknik, seperti buku rusak, hilang oleh siswa, dan lain-lain. Dilihat dari sisi kebutuhan sekolah sangat membutuhkan buku dengan rasio $1: 1$;

2. proses pelaporan administrasi BOS yang rumit, sedangkan sumber daya manusia di sekolah dasar tidak memiliki kemampuan yang baik dalam proses pelaporan BOS; 
3. dana BOS pada implementasinya mengalami keterlambatan, hal ini dikarenakan dengan panjangnya proses birokrasi yang ada. Keterlambatan ini terjadi berulang-ulang. Pada awalnya dana BOS diberikan melalui dana dekonsentrasi pemerintah propinsi dan langsung ke sekolah. Pencairan dana BOS diberikan setiap 3 bulan sekali, berdasarkan jumlah siswa yang ada dan langsung masuk ke rekening sekolah.

\section{Solusi terhadap Masalah-Masalah}

\section{yang Ada}

Penelitian ini memberikan masukan-masukan terhadap beberapa pernasalahan yang ada, yaitu sebagai berikut.

1. Pemerintah Pusat

a. Pemerintah pusat sebaiknya meningkatkan anggaran BOS regular, karena didalam komponen BOS regular terdapat biaya penyediaan buku teks sekolah. Dana BOS belum mencukupi rasio minimal untuk penyediaan buku sekolah. Diharapkan
Pemerintah pusat dalam hal ini Kementerian Pendidikan Nasional dapat membuat panduan dan mekanisme penyaluran dana BOS yang operasional.

b. BOS reguler mulai tahun 2011 ini berubah mekanisme pencairannya, yang sebelumnya langsung ke sekolah dari Kementerian Pendidikan Nasional, saat ini BOS masuk ke dalam anggaran APBD. Hal ini yang membuat adanya keterlambatan, mengingat perubahan tersebut membutuhkan waktu penyesuaian dan pembuatan perangkat-perangkat lainnya

c. Implementasi BOS yang khusus untuk penyediaan buku sekolah, lebih baik dalam bentuk buku, supaya sekolah tidak salah beli dan buku yang disediakan sudah sesuai dengan standar isi secara nasional. Secara umum BOS sudah berjalan relatif baik dan sesuai dengan petunjuk pelaksanaan dalam 
konteks penyediaan buku sekolah.

2. Pemberintah Daerah

Pemerintah daerah diharapkan menyediakan tambahan anggaran penyediaan buku sekolah, hal ini dilihat dari kebutuhan akan buku yang sangat tinggi. Pemerintah daerah juga perlu melakukan pengawasan untuk implementasi penggunaan dana BOS regular, agar pelaksanaannya sesuai dengan panduan yang ada.

3. Sekolah

Pihak sekolah harus proaktif melakukan networking dengan berbagai pihak agar sekolah mendapatkan tambahan anggaran dan fasilitas terutama terkait dengan penyediaan buku sekolah. Sekolah harus memperioritaskan kebutuhan siswa yang terkait dengan proses pembelajaran dibandingkan dengan belanja pekerjaan yang tidak terkait langsung dengan proses pembelajaran. Sekolah harus menjaga dan meningkatkan mutu pembelajaran dengan memberikan pelayanan yang baik terhadap siswa dan stakeholder sekolah.
4. Orang tua

Orang tua harus mendukung siswa/i dalam melakukan proses pembelajaran, termasuk dengan melengkapinya dengan fasilitas tambahan seperti buku-buku tambahan dan media pembelajaran lainnya. Dukungan orangtua sangat mempengaruhi peningkatan motivasi belajar siswa/i. Orangtua juga harus terlibat dalam proses pengambilan kebijakan di sekolah.

5. Penerbit atau Agen Buku Penerbit atau Agen buku harus mengutamakan kepentingan pendidikan, artinya kualitas buku yang baik dengan harga yang terjangkau. Walaupun saat ini ada BSE (buku sekolah elektronik) tetap saja untuk buku cetak sangat dibutuhkan oleh sekolah. Penerbit atau Agen buku juga harus menjadi fasilitator untuk mendukung peningkatan kualitas pendidikan di Indonesia

\section{PENUTUP}

Artikel dengan judul "Analisis Implementasi Kebijakan Bantuan Operasional Sekolah Buku untuk 
Sekolah Dasar" merupakan hasil penelitian dengan objek responden di kota Depok dengan empat kecamatan yaitu: Beji, Sawangan, Bojongsari, dan Pancoran Mas dengan pengambilan sampel purposive sebanyak 15 sekolah dasar.

Dalam hal sumber anggaran, hasil penelitian tersebut dapat disimpulkan bahwa (1) untuk dana penyediaan buku di sekolah berasal dari BOS Reguler, APBD, Orangtua siswa, dan sponsor untuk sekolah swasta; dan (2) sebanyak 8 sekolah (53\%) menyatakan anggaran tersebut cukup, dan 7 sekolah $(46,6 \%)$ menyatakan anggaran tersebut tidak cukup.

Buku Teks; untuk fasilitas buku, sebanyak 7 sekolah $(46,6 \%)$ sudah memiliki rasio buku 1 siswa : 1 buku, dan sebanyak 8 sekolah $(53,3 \%)$ yang belum memiliki rasio buku 1 siswa : 1 buku, maka seharusnya sekolah memenuhi standar pelayanan minimal yang

Buku Pengayaan/Bacaan; dilihat dari Buku Pengaayaan, sebanyak 9 sekolah $(60 \%)$ mendapatkan daftar dari dinas pendidikan kota Depok. Dana BOS digunakan untuk membeli buku jumlah buku sama dengan jumlah siswa. Mekanisme pembelian buku sebanyak 9 sekolah (60\%) membeli langsung ke Penerbit, dan sebanyak 6 sekolah (40\%) membeli buku melalui agen distributor. Sekolah dasar yang dijadikan sebagai sampel, sebanyak 15 sekolah (100\%) tidak meminta pungutan dana ke siswa, hal ini sudah mencerminkan implementasikan wajib belajar pendidikan dasar 9 tahun. Sekolah dasar dibebaskan dari pembayaran wajib.

Buku Pegangan Guru; Sekolah tidak diharuskan memiliki buku pegangan guru, sebanyak 10 sekolah $(66,6 \%)$ mendapatkan daftar buku dari dinas pendidikan kota depok dan sebanyak 5 sekolah $(33,3 \%)$ tidak mendapatkan daftar buku dari dinas pendidikan kota Depok. Dana BOS digunakan untuk membeli buku pegangan guru sebanyak 7 sekolah $(46,6 \%)$ dan 8 sekolah $(53,3 \%)$ tidak menggunakan dana BOS.

pengayaan sebanyak 7 sekolah $(46,6 \%)$.

Lembar Kerja Siswa; buku LKS, sebanyak 13 sekolah $(86,6 \%)$ tidak mendapatkan daftar dari dinas pendidikan kota Depok. Dana BOS 
untuk membelikan LKS hanya satu sekolah yang menggunakannya, yaitu SDN Pengasinan 01, yang lainnya tidak menggunakan dana BOS tetapi menggunakan dana dari siswa (orang tua).

Saran/masukan berdasarkan hasil penelitian ini ditujukan kepada beberapa pihak terkait, yaitu:

1) Pemerintah Pusat; sarannya agar meningkatkan anggaran BOS Reguler, karena didalamnya terdapat unsur penyediaan buku dan membuat panduan petunjuk pelaksanaan $\mathrm{BOS}$ reguler dan bantuan perbukuan lainnya.

2) Pemerintah Daerah; sarannya agar memberikan anggaran tambahan untuk penyediaan anggaran buku di sekolah.

3) Sekolah; sarannya sekolah harus proaktif mencari sumber-sumber pendanaan lainnya untuk peningkatan sarana prasarana sekolah khususnya buku. Di samping itu, sekolah harus menjalankan peraturan penyediaan buku sesuai dengan petunjuk pelaksanaan yang terdapat di petunjuk bantuan operasional sekolah
4) Masyarakat atau Orang tua; sarannya masyarakat atau orangtua sangat berperan penting dalam meningkatkan kualitas peserta didiknya. Dukungan dan motivasi orang tua akan menentukan kualitas proses pembelajaran yang dilakukan oleh peserta didik. Orang tua harus memberikan dukungan dalam pembelian buku atau penyediaan fasilitas sumber belajar yang mendukung peningkatan kualitas peserta didik. Hal ini sangat penting, kita melihat karakterisitk anak-anak Sekolah Dasar yang sangat membutuhkan dukungan dari orang tua.

\section{DAFTAR RUJUKAN}

Arikunto, Suharsimi, 1998. Prosedur Penelitian: Suatu Pendekatan. Teori dan Praktik Rineka Cipta.

Armstrong, M., 1990. Manajemen Sumber Daya Manusia. Seri Pedoman Manajemen. Cikmat Sofyan, Alih Bahasa. Jakarta: Elex Media Komputindo, Gramedia

Biro Pusat Statistik, 2002. Statistik Indonesia. Statistical Year 
Book of Indonesia. JakartaIndonesia: Biro Pusat Statistik.

Donnely. Ivancevich dan Gibson. 1993. Organisasi dan Manajemen. Perilaku Struktur Proses. Jakarta: Erlangga.

Gibson, et al, 1993. Organisasi dan Manajemen: Perilaku, Struktur. Proses. Penerjemah: Djoerban Wahid. Jakarta: Erlangga.

Departemen Perdagangan, Survey Industri Kreatif di Indonesia Tahun 2007

Esterberg, Kristin G: Qualitative Methods in social research, Mc Grawhill, New York, 2002

Irawan, Prasetya,2006: Penelitian Kualitatif dan Kuantitatif untuk ilmu-ilmu sosial, Departemen Ilmu Administrasi, Universitas Indonesia

Martaniah, Mulyani. S, 1964. Peranan Orang Tua dalam Perkembangan Kepribadian. Yogyakarta: Jiwa Baru 11/12 Th XII.
Permendiknas RI Nomor 28 Tahun 2008 tentang "Perubahan Atas Peraturan Menteri Pendidikan Nasional Nomor 13 Tahun 2008 tentang Harga Eceran Tertinggi

Robert Woods, Printing Production for Promotional Materials

Sugiyono, Metode Penelitian Kuantitatif, Kualitatif dan $R \& D, \quad$ Alfabeta, Bandung; 2006

Undang-Undang Sistem Pendidikan Nasional No 20 Tahun 2003

Undang-Undang Perpustakaan, yaitu Undang-Undang No 43 Tahun 2007

Winardi. Faktor Pendorong Minat Beli dalam Bisnis. Jakarta: Mizan, 1991

http://www.koranpendidikan.com/art ikel/1917/tentang-bse.html http://bse.depdiknas.go.id 